OPEN ACCESS

Edited by:

James (Jim) David Cotter,

University of Otago, New Zealand

Reviewed by:

Moacir Marocolo,

Juiz de Fora Federal University, Brazil

Gustavo R. Mota,

Federal University of Triângulo

Mineiro, Brazil

*Correspondence:

Ira Jacobs

ira.jacobs@utoronto.ca

Specialty section:

This article was submitted to

Exercise Physiology

a section of the journal

Frontiers in Physiology

Received: 21 January 2021

Accepted: 07 April 2021

Published: 29 April 2021

Citation:

O'Brien L and Jacobs I (2021)

Methodological Variations

Contributing to Heterogenous

Ergogenic Responses to Ischemic

Preconditioning.

Front. Physiol. 12:656980.

doi: 10.3389/fphys.2021.656980

\section{Methodological Variations Contributing to Heterogenous Ergogenic Responses to Ischemic Preconditioning}

\author{
Liam O'Brien and Ira Jacobs* \\ Human Physiology Laboratory, Faculty of Kinesiology and Physical Education, University of Toronto, Toronto, ON, Canada
}

Ischemic preconditioning (IPC) has been repeatedly reported to augment maximal exercise performance over a range of exercise durations and modalities. However, an examination of the relevant literature indicates that the reproducibility and robustness of ergogenic responses to this technique are variable, confounding expectations about the magnitude of its effects. Considerable variability among study methodologies may contribute to the equivocal responses to IPC. This review focuses on the wide range of methodologies used in IPC research, and how such variability likely confounds interpretation of the interactions of IPC and exercise. Several avenues are recommended to improve IPC methodological consistency, which should facilitate a future consensus about optimizing the IPC protocol, including due consideration of factors such as: location of the stimulus, the time between treatment and exercise, individualized tourniquet pressures and standardized tourniquet physical characteristics, and the incorporation of proper placebo treatments into future study designs.

Keywords: ischemic preconditioning, exercise, ergogenic aid, IPC exercise, athletic performance, aerobic exercise, anaerobic exercise, athlete

\section{INTRODUCTION}

The induction of transient cycles of arterial blood flow occlusion and reperfusion confers beneficial effects on tissues undergoing subsequent ischemic insults. This technique, known as ischemic preconditioning (IPC), has been shown to improve tissue tolerance to subsequent ischemia in tissues subject to the ischemic intervention (Murry et al., 1986; Dickson et al., 2000), and also remotely located tissues (Kristiansen et al., 2005; Shimizu et al., 2007). Remote IPC (RIPC) is known to promote cardioprotective (Konstantinov et al., 2005; Kristiansen et al., 2005), and neuroprotective effects against infarction in animal models (Pérez-Pinzón, 2004; Liu et al., 2016; Wang et al., 2016). However, evidence of such protection in humans is equivocal.

Perhaps it is this strong evidence of improved local and systemic tissue protection found in animal models that led to the interest of exercise scientists in IPC as a potential ergogenic aid for improving athletic performance. That interest has resulted in several reports demonstrating that both IPC and RIPC can confer positive effects on exercise performance over a variety of exercise intensities, durations, and modalities (Jean-St-Michel et al., 2011; Paradis-Deschênes et al., 2016; Paull and Van Guilder, 2019). But not all studies have reported ergogenic effects with IPC interventions (For review on the ergogenic responses to IPC see: Marocolo et al., 2015b, 2019; Incognito et al., 2016; Salvador et al., 2016; Caru et al., 2019b). Incognito et al. (2016) reported 
positive IPC response rates of 70 and $74 \%$ during time trials of predominantly aerobic and glycolytic anaerobic capacity, respectively. Marocolo et al. (2015b) reported that out of 20 high-quality IPC exercise studies, the majority did not report significant changes to athletic performance or related physiological mediators of performance following IPC interventions. In contrast, and more recently, Caru et al. (2019b) reviewed 52 high-quality articles and found that most studies demonstrated beneficial effects on performance. Our interpretation of these different perspectives is that the influence of IPC on exercise and athletic performance remains equivocal. Moreover, the challenges of publishing negative findings may have further obfuscated the literature on the efficacy of IPC on exercise performance.

In this review we propose that one of the reasons for the equivocal findings may be the widely varying methodological approaches to IPC interventions reported in the literature (Table 1). The primary objective of the current review is, therefore, to describe and consider these variations. Table 1 has been constructed to succinctly describe key aspects of the IPC methodologies used in the IPC exercise studies reported in English language literature to date.

A consequence of the methodological variations reported in the literature relate to the identification of the physiological mediators of the beneficial effects of IPC. Information gleaned from clinical experiments suggests that the protective effects of IPC operate through neuronal, humoral, and systemic pathways (Marongiu and Crisafulli, 2014). Others propose that IPC promotes reactive hyperemia mediated by nitric oxide production (Singh et al., 2017), phosphocreatine resynthesis (Andreas et al., 2011), peripheral hemodynamics (ParadisDeschênes et al., 2016; Cocking et al., 2018a; Halley et al., 2018), and skeletal muscle oxygen uptake (Andreas et al., 2011; Paradis-Deschênes et al., 2016). Such physiological responses have a theoretical basis that would support enhanced exercise performance capacity, but the heterogeneous methodologies described in Table 1 and the varying positive response rates to IPC reported in the literature, when considered together, challenge the confident identification of physiological mediators of performance changes associated with IPC. This knowledge gap similarly challenges knowledge transfer and application, specifically being able to confidently predict whether an IPC intervention is likely to result in ergogenic effects.

\section{METHODOLOGICAL VARIATIONS CONTRIBUTING TO HETEROGENEOUS RESPONSES}

\section{IPC Protocol}

There appears to be no scientific consensus regarding the IPC protocol most likely to elicit an ergogenic effect. Table 1 demonstrates that there are substantial variations in the chosen IPC protocols. For example, the number of ischemic cycles used has ranged from one to eight cycles (Libonati et al., 1998; Cocking et al., 2018b), and the durations of ischemia have ranged from 2 to $10 \mathrm{~min}$ (Libonati et al., 1998; Andreas et al., 2011). Most, but not all investigations allow for a duration for reperfusion between ischemic intervals that is equal to the duration of the ischemic interval, however, some studies have utilized longer (Andreas et al., 2011) or shorter reperfusion intervals (Libonati et al., 1998; Garcia et al., 2017; Mota et al., 2020). The most common IPC protocols have been four (47\% of studies) or three ( $42 \%$ of studies) cycles of 5 min ischemia-reperfusion. Most reports to date have conducted their exercise testing acutely on the same day as the IPC stimulus. However, a minority of studies have conducted exercise testing after repeated daily IPC exposure ranging from 7 days to 6 weeks (Banks et al., 2016; Jeffries et al., 2019; Slysz and Burr, 2019; Mieszkowski et al., 2020; Paradis-Deschênes et al., 2020a; Surkar et al., 2020). There also is substantial variation in whether IPC is administered unilaterally or bilaterally to the $\operatorname{limb}(\mathrm{s})$, which may influence the magnitude of response. Such heterogeneous methods confound the comparison of results among various studies.

Understanding whether or not there is an optimal doseresponse for IPC would seem to be integral to clarifying the probability of beneficial effects on a specified type, duration, or intensity of exercise performance. Surprisingly few studies have compared and contrasted the effects of different IPC protocols on exercise performance outcomes. Turnes et al. (2018) compared three cycles of $5 \mathrm{~min}$ vs. $10 \mathrm{~min}$ IPC but did not find a benefit of either treatment on rowing ergometry performance. De Groot et al. (2010) demonstrated that fewer than three cycles of IPC had negligible effects on athletic performance whereas Cocking et al. (2018b) did not find additional benefits of IPC when comparing eight cycles to four cycles of $5 \mathrm{~min}$ IPC. These authors also found that a unilateral IPC approach resulted in significantly slower cycling time trial performance compared to bilateral IPC which suggests that the IPC response is contingent on the total tissue area under ischemia. It has been suggested that the protective effects of IPC might require achieving a physiological disruption that is reflected in the accumulation of metabolites above a threshold, eliciting synergistic effects that propagate the IPC response (Cohen et al., 2000; Marongiu and Crisafulli, 2014). Such a theory implies that the total volume of tissue and/or duration of ischemia-reperfusion may be important to meet this metabolite threshold. Additional effects of IPC may also be dependent on the time or frequency of the IPC stimulus. For example, the degree of RIPC induced conduit artery vasodilation has been shown to be dependent on the number of ischemic cycles (Enko et al., 2011), and the hyperemic response to tourniquet occlusion is dependent on the duration of ischemia (Johnson et al., 1976).

Taken together, this evidence suggests that the probability and magnitude of an ergogenic response to IPC is a function of an "entourage" effect that is a cumulative consequence of some combination of duration, frequency, and/or tissue volume dependent stimulus. Until further research clarifies the magnitude of the individual and entourage contributions, the evidence in Table 1 leads to our recommendation that IPC protocols should entail at least three cycles of $5 \mathrm{~min}$ ischemiareperfusion, and that IPC should be applied bilaterally based on the observations of increased performance when occluding both limbs compared to one (Cocking et al., 2018b). 
TABLE 1 | Methodological summary of studies examining IPC on exercise performance variables.

\begin{tabular}{|c|c|c|c|c|c|c|c|c|c|}
\hline References & Exercise & $\begin{array}{l}\text { Type of } \\
\text { IPC }\end{array}$ & $\begin{array}{l}\text { Location of } \\
\text { IPC }\end{array}$ & Protocol & \multicolumn{3}{|c|}{ Treatment } & $\begin{array}{l}\text { Method to } \\
\text { confirm AOP }\end{array}$ & $\begin{array}{l}\text { Time to } \\
\text { exercise }\end{array}$ \\
\hline $\begin{array}{l}\text { Andreas et al. } \\
\text { (2011) }\end{array}$ & $\begin{array}{l}\text { Isometric } \\
\text { plantarflexion } \\
\text { MVC }\end{array}$ & Acute IPC & $\begin{array}{l}\text { Right thigh } \\
\text { (unilateral) }\end{array}$ & $\begin{array}{l}3 \times 5 \min + \\
10 \text { min } \\
\text { reperfusion }\end{array}$ & $200 \mathrm{~mm} \mathrm{Hg}$ & Reference test & None & NA & Immediately \\
\hline $\begin{array}{l}\text { Arriel et al. } \\
\text { (2020) }\end{array}$ & $\begin{array}{l}\text { Incremental } \\
\text { exercise test } \\
\text { (Cycling) }\end{array}$ & Acute IPC & $\begin{array}{l}\text { Alternate } \\
\text { thighs } \\
\text { (unilateral) }\end{array}$ & $2 \times 5 \min$ & $50 \mathrm{~mm} \mathrm{Hg}>\mathrm{SBP}$ & No occlusion & $20 \mathrm{~mm} \mathrm{Hg}$ & NA & NA \\
\hline $\begin{array}{l}\text { Baikoglu and } \\
\text { Kaldirimci (2019) }\end{array}$ & $\begin{array}{l}\text { Wingate } \\
\text { Anaerobic Test }\end{array}$ & Acute IPC & $\begin{array}{l}\text { Thigh } \\
\text { (bilateral) }\end{array}$ & $1 \times 5 \min$ & NA & Reference test & None & NA & Immediately \\
\hline $\begin{array}{l}\text { Banks et al. } \\
(2016)\end{array}$ & $\begin{array}{l}\text { Incremental } \\
\text { exercise test } \\
\text { (Cycling) }\end{array}$ & $\begin{array}{l}\text { Repeat } \\
\text { RIPC }\end{array}$ & $\begin{array}{l}\text { Right arm } \\
\text { (unilateral) }\end{array}$ & $\begin{array}{l}4 \times 5 \text { min for } \\
9 \text { days }\end{array}$ & 200 mm Hg & Reference test & None & NA & $24 \mathrm{~h}$ \\
\hline $\begin{array}{l}\text { Barbosa et al. } \\
\text { (2015) }\end{array}$ & $\begin{array}{l}\text { Rhythmic } \\
\text { handgrip TTE at } \\
45 \% \text { MVC }\end{array}$ & Acute & $\begin{array}{l}\text { Thigh } \\
\text { (bilateral) }\end{array}$ & $3 \times 5 \min$ & 200 mm Hg & $10 \mathrm{~mm} \mathrm{Hg}$ & None & Doppler & $25 \mathrm{~min}$ \\
\hline $\begin{array}{l}\text { Beaven et al. } \\
\text { (2012) }\end{array}$ & $\begin{array}{l}\text { Lower body } \\
\text { strength/power } \\
\text { testing + repeat } \\
\text { sprint (Running) }\end{array}$ & Acute & $\begin{array}{l}\text { Alternate } \\
\text { thighs } \\
\text { (unilateral) }\end{array}$ & $2 \times 3 \min$ & $220 \mathrm{~mm} \mathrm{Hg}$ & $15 \mathrm{~mm} \mathrm{Hg}$ & None & NA & Immediately \\
\hline $\begin{array}{l}\text { Behrens et al. } \\
\text { (2020) }\end{array}$ & $\begin{array}{l}\text { Isometric knee } \\
\text { extension TTE at } \\
20 \% \text { MVC }\end{array}$ & Acute & IPC (legs) & $3 \times 5 \min$ & $120 \%$ AOP & None & $20 \mathrm{~mm} \mathrm{Hg}$ & Doppler & $20 \mathrm{~min}$ \\
\hline $\begin{array}{l}\text { Carvalho and } \\
\text { Barroso (2019b) }\end{array}$ & $\begin{array}{l}85 \% 1 \mathrm{RM} \text { knee } \\
\text { extension to } \\
\text { failure }\end{array}$ & Acute IPC & $\begin{array}{l}\text { Alternate } \\
\text { thighs } \\
\text { (unilateral) }\end{array}$ & $4 \times 5 \min$ & $250 \mathrm{~mm} \mathrm{Hg}$ & None & $10 \mathrm{~mm} \mathrm{Hg}$ & NA & $30 \mathrm{~min}$ \\
\hline $\begin{array}{l}\text { Carvalho and } \\
\text { Barroso (2019a) }\end{array}$ & $\begin{array}{l}\text { Isometric knee } \\
\text { extension MVC } \\
\text { test }\end{array}$ & Acute IPC & $\begin{array}{l}\text { Alternate } \\
\text { thighs } \\
\text { (unilateral) }\end{array}$ & $4 \times 5 \min$ & $250 \mathrm{~mm} \mathrm{Hg}$ & None & $10 \mathrm{~mm} \mathrm{Hg}$ & NA & NA \\
\hline $\begin{array}{l}\text { Cheung et al. } \\
\text { (2020) }\end{array}$ & $\begin{array}{l}\text { Incremental } \\
\text { exercise test } \\
\text { (Cycling) }\end{array}$ & Acute IPC & $\begin{array}{l}\text { Alternate } \\
\text { thighs } \\
\text { (unilateral) }\end{array}$ & $4 \times 5 \min$ & Individual AOP & $\begin{array}{l}40 \text { min supine } \\
\text { passive rest }\end{array}$ & $\begin{array}{l}\text { Therapeutic } \\
\text { ultrasound }\end{array}$ & $\begin{array}{l}\text { Personal } \\
\text { Tourniquet } \\
\text { System }\end{array}$ & Immediately \\
\hline $\begin{array}{l}\text { Clevidence et al. } \\
\text { (2012) }\end{array}$ & $\begin{array}{l}\text { Incremental } \\
\text { exercise test } \\
\text { (Cycling) }\end{array}$ & Acute IPC & $\begin{array}{l}\text { Alternate } \\
\text { thighs } \\
\text { (unilateral) }\end{array}$ & $3 \times 5 \min$ & $220 \mathrm{~mm} \mathrm{Hg}$ & $\begin{array}{l}30 \text { min supine } \\
\text { passive rest }\end{array}$ & None & NA & $5 \mathrm{~min}$ \\
\hline $\begin{array}{l}\text { Cocking et al. } \\
\text { (2017) }\end{array}$ & $1 \mathrm{~h} \pi$ (Cycling) & $\begin{array}{l}\text { Acute IPC } \\
\text { and RIPC }\end{array}$ & $\begin{array}{l}\text { Alternate } \\
\text { arms and } \\
\text { thighs } \\
\text { (bilateral) }\end{array}$ & $4 \times 5 \min$ & $220 \mathrm{~mm} \mathrm{Hg}$ & $20 \mathrm{~mm} \mathrm{Hg}$ & None & NA & Immediately \\
\hline $\begin{array}{l}\text { Cocking et al. } \\
\text { (2018b) }\end{array}$ & $\begin{array}{l}375 \text { kJ TT } \\
\text { (Cycling) }\end{array}$ & $\begin{array}{l}\text { Acute IPC } \\
+ \text { RIPC }\end{array}$ & $\begin{array}{l}\text { Thigh } \\
\text { (bilateral) } \\
\text { Left thigh } \\
\text { (unilateral) } \\
\text { Arm (bilateral) } \\
\text { Thigh (bilateral) }\end{array}$ & $\begin{array}{l}4 \times 5 \min \\
4 \times 5 \min \\
4 \times 5 \min \\
8 \times 5 \min \end{array}$ & $220 \mathrm{~mm} \mathrm{Hg}$ & $20 \mathrm{~mm} \mathrm{Hg}$ & None & NA & $20 \mathrm{~min}$ \\
\hline
\end{tabular}


TABLE 1 | Continued

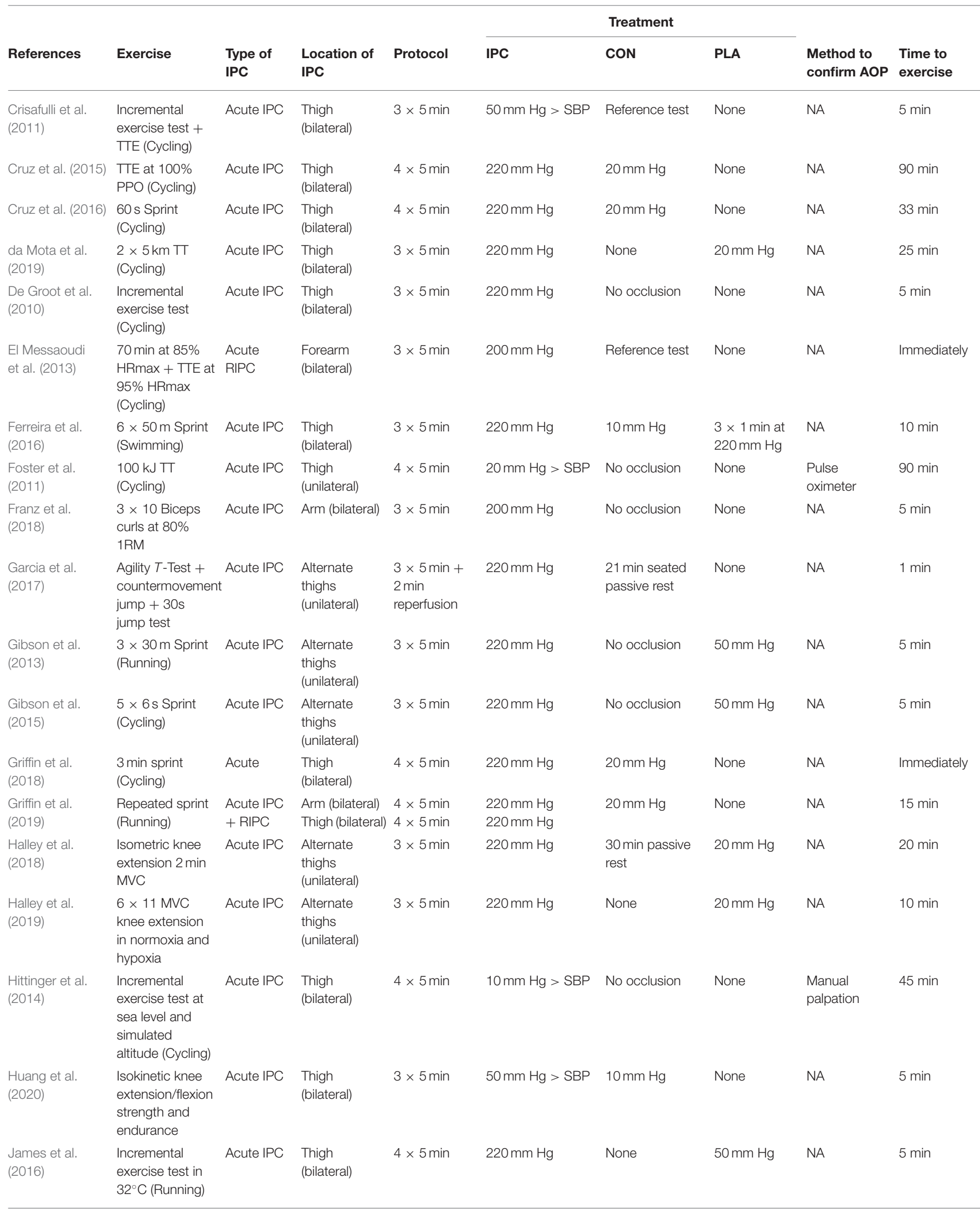


TABLE 1 | Continued

\begin{tabular}{|c|c|c|c|c|c|c|c|c|c|}
\hline References & Exercise & $\begin{array}{l}\text { Type of } \\
\text { IPC }\end{array}$ & $\begin{array}{l}\text { Location of } \\
\text { IPC }\end{array}$ & Protocol & \multicolumn{3}{|c|}{ Treatment } & $\begin{array}{l}\text { Method to } \\
\text { confirm AOP }\end{array}$ & $\begin{array}{l}\text { Time to } \\
\text { exercise }\end{array}$ \\
\hline $\begin{array}{l}\text { Jean-St-Michel } \\
\text { et al. (2011) }\end{array}$ & $\begin{array}{l}7 \times 200 \mathrm{~m} \\
\text { submaximal }+ \\
100 / 200 \mathrm{~m} \pi \\
\text { (Swimming) }\end{array}$ & $\begin{array}{l}\text { Acute } \\
\text { RIPC }\end{array}$ & $\begin{array}{l}\text { Arm } \\
\text { (unilateral) }\end{array}$ & $4 \times 5 \min$ & $15 \mathrm{~mm} \mathrm{Hg}>\mathrm{SBP}$ & $10 \mathrm{~mm} \mathrm{Hg}$ & None & NA & $45 \mathrm{~min}$ \\
\hline Kaur et al. (2017) & $\begin{array}{l}\text { Incremental } \\
\text { submaximal } \\
\text { (Running) }\end{array}$ & Acute IPC & $\begin{array}{l}\text { Thigh } \\
\text { (bilateral) }\end{array}$ & $3 \times 5 \min$ & 220 mm Hg & $20 \mathrm{~mm} \mathrm{Hg}$ & None & NA & $15 \mathrm{~min}$ \\
\hline $\begin{array}{l}\text { Kjeld et al. } \\
\text { (2014) }\end{array}$ & $\begin{array}{l}\text { Static/dynamic } \\
\text { apnea + } 1000 \mathrm{~m} \\
\Pi \text { (Rowing) }\end{array}$ & $\begin{array}{l}\text { Acute } \\
\text { RIPC }\end{array}$ & $\begin{array}{l}\text { Forearm } \\
\text { (unilateral) }\end{array}$ & $4 \times 5$ & $40 \mathrm{~mm} \mathrm{Hg}>\mathrm{SBP}$ & No occlusion & None & NA & $30 \mathrm{~min}$ \\
\hline $\begin{array}{l}\text { Kraus et al. } \\
(2015)\end{array}$ & $\begin{array}{l}4 \times 30 \mathrm{~s} \\
\text { Wingate } \\
\text { Anaerobic Test }\end{array}$ & $\begin{array}{l}\text { Acute } \\
\text { RIPC }\end{array}$ & $\begin{array}{l}\text { Left arm } \\
\text { (unilateral) } \\
\text { Arm (bilateral) }\end{array}$ & $4 \times 5 \min$ & NA & $10 \mathrm{~mm} \mathrm{Hg}$ & None & NA & $15 \mathrm{~min}$ \\
\hline $\begin{array}{l}\text { Lalonde and } \\
\text { Curnier (2015) }\end{array}$ & $\begin{array}{l}6 \text { s Sprint + } \\
\text { Wingate } \\
\text { Anaerobic Test }\end{array}$ & $\begin{array}{l}\text { Acute } \\
\text { RIPC }\end{array}$ & $\begin{array}{l}\text { Right arm } \\
\text { (unilateral) }\end{array}$ & $4 \times 5 \min$ & $50 \mathrm{~mm} \mathrm{Hg}>\mathrm{SBP}$ & $10 \mathrm{~mm} \mathrm{Hg}$ & None & NA & NA \\
\hline $\begin{array}{l}\text { Libonati et al. } \\
\text { (1998) }\end{array}$ & $\begin{array}{l}15 \times \text { isometric } \\
\text { wrist flexion } \\
\text { MVC }\end{array}$ & Acute IPC & $\begin{array}{l}\text { Forearm } \\
\text { (unilateral) }\end{array}$ & $\begin{array}{l}1 \times 2 \mathrm{~min}+ \\
10 \mathrm{~s} \\
\text { reperfusion }\end{array}$ & 200 mm Hg & No occlusion & None & NA & Immediately \\
\hline $\begin{array}{l}\text { Marocolo et al. } \\
\text { (2016b) }\end{array}$ & $\begin{array}{l}12 \mathrm{RM} \text { leg } \\
\text { extension }\end{array}$ & Acute IPC & $\begin{array}{l}\text { Alternate } \\
\text { thighs } \\
\text { (unilateral) }\end{array}$ & $4 \times 5 \min$ & 220 mm Hg & $\begin{array}{l}40 \text { min seated } \\
\text { passive rest }\end{array}$ & $20 \mathrm{~mm} \mathrm{Hg}$ & Auscultation & $8 \mathrm{~min}$ \\
\hline $\begin{array}{l}\text { Marocolo et al. } \\
\text { (2015a) }\end{array}$ & $\begin{array}{l}100 \mathrm{~m} T \mathrm{~T} \\
\text { (Swimming) }\end{array}$ & Acute IPC & $\begin{array}{l}\text { Alternate } \\
\text { arms } \\
\text { (unilateral) }\end{array}$ & $4 \times 5 \min$ & 220 mm Hg & $\begin{array}{l}40 \text { min passive } \\
\text { rest }\end{array}$ & $20 \mathrm{~mm} \mathrm{Hg}$ & NA & $5 \mathrm{~min}$ \\
\hline $\begin{array}{l}\text { Marocolo et al. } \\
\text { (2016a) }\end{array}$ & $\begin{array}{l}12 \mathrm{RM} \text { elbow } \\
\text { flexion }\end{array}$ & $\begin{array}{l}\text { Acute IPC } \\
+ \text { RIPC }\end{array}$ & $\begin{array}{l}\text { Alternate } \\
\text { arms or } \\
\text { thighs } \\
\text { (unilateral) }\end{array}$ & $4 \times 5 \min$ & 220 mm Hg & Reference test & $20 \mathrm{~mm} \mathrm{Hg}$ & Auscultation & $6 \mathrm{~min}$ \\
\hline $\begin{array}{l}\text { Marocolo et al. } \\
\text { (2017) }\end{array}$ & $\begin{array}{l}\text { Incremental } \\
\text { shuttle run }\end{array}$ & Acute IPC & $\begin{array}{l}\text { Alternate } \\
\text { thighs } \\
\text { (unilateral) }\end{array}$ & $4 \times 5 \min$ & 220 mm Hg & $\begin{array}{l}40 \text { min seated } \\
\text { passive rest }\end{array}$ & 20 mm Hg & Auscultation & $6 \mathrm{~min}$ \\
\hline $\begin{array}{l}\text { Mcllvenna et al. } \\
\text { (2019) }\end{array}$ & $\begin{array}{l}\text { Incremental } \\
\text { exercise test + } \\
16.1 \mathrm{~km} \mathrm{TT} \\
\text { (Cycling) }\end{array}$ & Acute IPC & $\begin{array}{l}\text { Thigh } \\
\text { (bilateral) }\end{array}$ & $3 \times 5 \min$ & $180 \mathrm{~mm} \mathrm{Hg}$ & Reference test & None & Doppler & $10 \mathrm{~min}$ \\
\hline $\begin{array}{l}\text { Mieszkowski } \\
\text { et al. (2020) }\end{array}$ & $\begin{array}{l}\text { Marathon } \\
\text { running }\end{array}$ & $\begin{array}{l}\text { Repeat } \\
\text { IPC }\end{array}$ & $\begin{array}{l}\text { Thigh } \\
\text { (bilateral) }\end{array}$ & $\begin{array}{l}4 \times 5 \text { min for } \\
10 \text { days }\end{array}$ & $220 \mathrm{~mm} \mathrm{Hg}$ & $20 \mathrm{~mm} \mathrm{Hg}$ & None & Doppler & $24 \mathrm{~h}$ \\
\hline
\end{tabular}


TABLE 1 | Continued

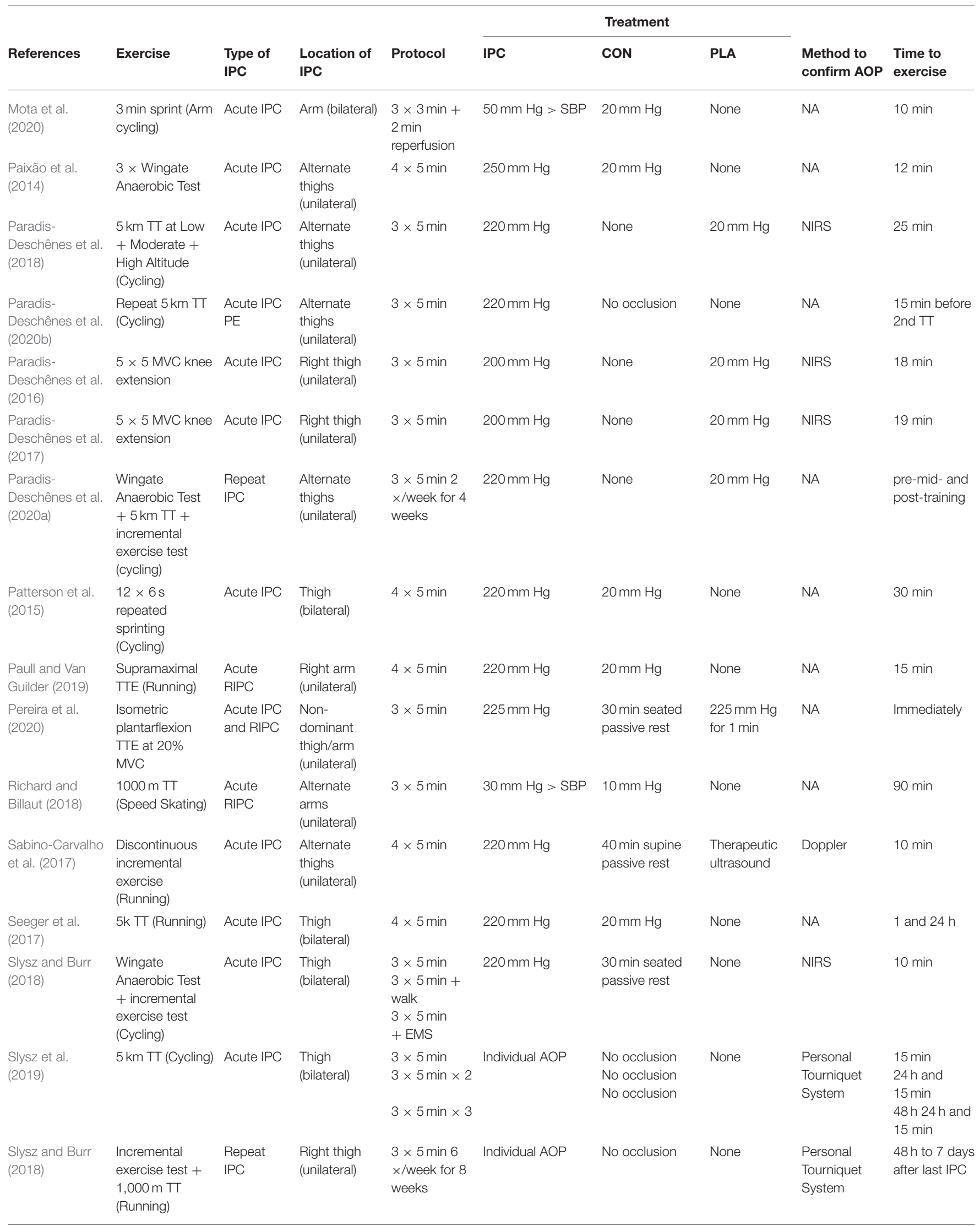


TABLE 1 | Continued

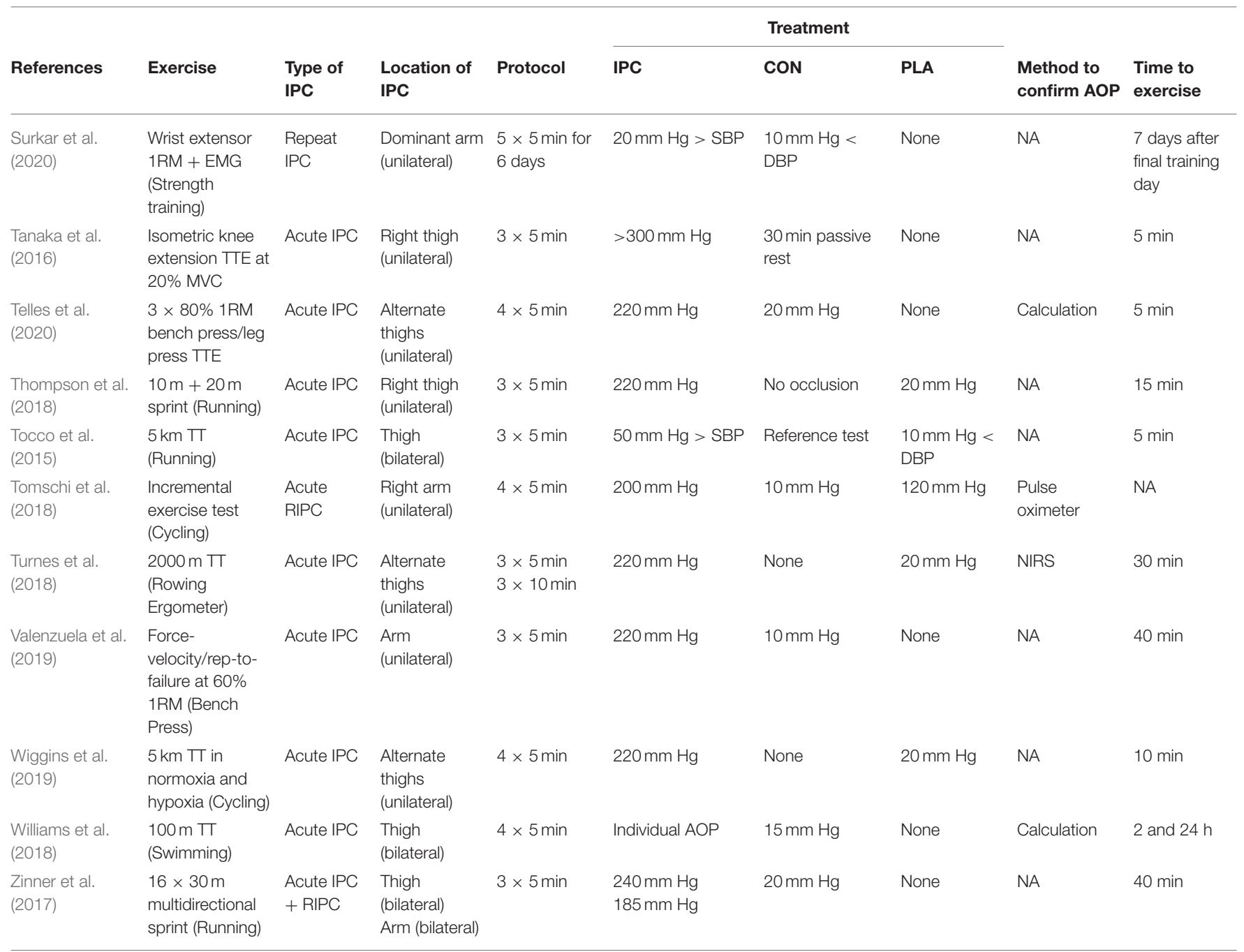

$A O P$, arterial occlusion pressure; CON, control condition; DBP, diastolic blood pressure; EMG, electromyography; EMS, electrical muscle stimulation; GET, gas exchange threshold; HRmax, maximal heart rate; IPC, ischemic preconditioning; IPC and RIPC, both local and remote ischemic preconditioning applied simultaneously; IPC + RIPC, local and remote ischemic preconditioning applied on separate visits; MVC, maximal voluntary contraction; NA, not available; NIRS, near infrared spectroscopy; PE, post-exercise; PLA, placebo condition; PPO, peak power output; RIPC, remote ischemic preconditioning; SBP, systolic blood pressure; TTE, time to exhaustion; TT, time trial; 1RM, one repetition maximum; 12RM, twelve repetition maximum. The distinction between low-pressure CON and low-pressure PLA treatments was made based on whether the original investigators attempted to blind participants to the treatment through deception or nocebo techniques. Investigations that have utilized low-pressure treatments but have not attempted to blind participants to the different treatment pressures are defined as control treatments in this table.

\section{Absolute vs. Relative Tourniquet Pressures}

Perhaps the most pervasive source of methodological variability within the IPC exercise research is the tourniquet pressures chosen to elicit IPC. Table 1 indicates that pressures have ranged from $10 \mathrm{~mm} \mathrm{Hg}$ above systolic blood pressure (Hittinger et al., 2014) to those in excess of $300 \mathrm{~mm} \mathrm{Hg}$ (Kido et al., 2015; Tanaka et al., 2016). The literatures suggests that absolute tourniquet pressures in the range of $200-250 \mathrm{~mm} \mathrm{Hg}$ have been commonly used regardless of body size. The use of these absolute pressures appear to be largely based on favorable responses reported in previous publications (De Groot et al., 2010; Ferreira et al., 2016; Garcia et al., 2017). Yet, it is surprising given how widely variable arterial occlusion pressures (AOP) are among individuals, not to mention the potential for vast differences in the physical characteristics of the tourniquet. Lack of consideration of individual AOP may augment safety risks as higher tourniquet pressures are associated with greater risks of tourniquet-related injuries (Ochoa et al., 1972; Murphy et al., 2005). Thus, to minimize the risk and maximize the outcome, the minimum pressure required to prevent the flow of arterial blood into the limb should be established whenever possible in IPC interventions.

Past studies have demonstrated individual variations in lower limb AOP ranging from $100 \mathrm{~mm} \mathrm{Hg}$ to above $300 \mathrm{~mm} \mathrm{Hg}$ (Loenneke et al., 2012, 2013). These differences can be attributed to a multitude of factors including limb circumference, blood pressure, and biological sex (Crenshaw et al., 1988; Graham et al., 1993; Loenneke et al., 2015; Brown et al., 2018). Limbs 
with larger tissue masses require higher tourniquet pressures to achieve arterial occlusion (Graham et al., 1993; Loenneke et al., 2015). This would seem to constitute an important consideration for determining the tourniquet pressures to use when applying IPC to male vs. female or trained vs. untrained individuals. Body position also affects AOP as demonstrated by Sieljacks et al. (2018) who reported the need for larger tourniquet pressures to occlude leg blood flow in the seated position compared with the supine position. The dimensions of the tourniquet itself should also be considered as wider cuffs with evenly distributed pressure gradients require lower external pressures to sufficiently occlude blood flow compared to narrow cuffs (Crenshaw et al., 1988; Loenneke et al., 2012; Brown et al., 2018). In light of the preceding discussion, we contend that it is likely an erroneous assumption that all participants will experience a similar level of arterial constriction with the application of the same tourniquet pressure.

Despite these important considerations, two-thirds of the IPC exercise studies found in Table 1 have failed to report any confirmation of AOP. Only five of the 81 studies have prescribed pressures relative to individual AOP. Therefore, it cannot be concluded that all subjects in these analyses attained similar and/or sufficient degrees of ischemia to stimulate a response. We posit that this may contribute to the equivocal findings reported in the literature and/or the variation in response rates within the same study. We recommend that the identification of individual minimal AOP is a key parameter that should be monitored continuously during the IPC intervals to ensure the absence of persistent blood flow, reported, and used in future IPC research.

\section{Remote or Local IPC}

It seems reasonable to speculate that the location of the IPC stimulus relative to the musculature that will be activated during subsequent exercise might impact the success of the intervention. Most of the studies reviewed in Table 1 have utilized local IPC applied in close proximity to the muscle groups that will be exercising, with mixed success in finding an ergogenic effect. Eighteen of the 81 studies examined RIPC on exercise performance. Of those reports, few have directly compared the effects of IPC and RIPC on performance outcomes. Based on the limited available evidence, there does not appear to be a difference in performance outcomes between IPC and RIPC interventions; three studies have shown no effect of either technique on performance (Marocolo et al., 2016a; Zinner et al., 2017; Griffin et al., 2019) whereas one showed similar improvements for both on cycling performance (Cocking et al., 2018b).

The evidence that central humoral, neural, and systemic ischemic protection mediate IPC benefits suggests that the location of the application of IPC may not have an optimal site of application. Alternatively, muscle deoxygenation responses during exercise preceded by local (Paradis-Deschênes et al., 2016, 2020a), but not always remote IPC (Barbosa et al., 2015), may suggest that the IPC stimulus is optimized when administered in close proximity to the exercising tissues. Without a comprehensive understanding of the mechanisms most likely to elicit an ergogenic response, it is difficult to determine if there are advantages favoring remote or local IPC in terms of the probability of an ergogenic effect. More focused research is definitely required about this issue.

\section{Time Between IPC Application and Exercise}

It remains unclear what the optimal duration is between completion of IPC application and the start of exercise. This is surprising because it also seems to be a relatively fundamental assumption that such an optimal duration should exist. The void of information likely also contributes to the varied responses reported in the literature. Table 1 demonstrates the wide range of durations between IPC and exercise testing used throughout the literature. Most studies ( $70 \%)$ report beginning exercise within the first $30 \mathrm{~min}$ after IPC, however several studies reported commencing exercise between $30 \mathrm{~min}$ to $72 \mathrm{~h}$ after IPC depending on the objectives of the investigation. We conclude that the chosen interval between IPC and exercise appears to be largely arbitrary as few investigations have sought to compare the effects of different durations on performance.

An improved understanding of the mediators of ischemic protection associated with IPC, and how they may mediate ergogenic effects is integral to identifying the optimal timeto-exercise after IPC. For example, the hyperemic response following IPC is not likely to persist beyond the initial several minutes following IPC. Moreover, it is not clear how long after IPC that increases in exercising muscle $\mathrm{O}_{2}$ extraction persist. Based on these phenomena alone, one may conclude that immediate exercise is favorable for eliciting an ergogenic response through enhanced convective $\mathrm{O}_{2}$ delivery and diffusion at the muscle capillary interface. Nonetheless, the contribution of the protective effects against ischemia from IPC are equivocal when it comes to their application to exercise. Therefore, we do not know if the mediators of the purported ergogenic response occur relatively instantaneous or if there is a latent response.

For purposes of comparison, in clinical studies IPC is known to have two windows of protection characterized by substantial reductions in tissue infarct size during sustained ischemia. The first window of protection lasts $\sim 3 \mathrm{~h}$ after application of IPC, followed by a $12-24 \mathrm{~h}$ period without protective effects. Then, a second window of protection occurs that lasts upwards of 72-90 h from the IPC stimulus (Pagliaro et al., 2001; Marongiu and Crisafulli, 2014). The persistence of these protective windows may help explain why IPC has been shown to influence performance 8-24 h after application (Lindsay et al., 2017; Lisbôa et al., 2017). Still, we contend that the optimal duration between IPC and exercise has not been sufficiently explored to permit confidence in drawing conclusions. Seeger et al. (2017) compared $5 \mathrm{~km}$ treadmill running tests $5 \mathrm{~min}$ and $24 \mathrm{~h}$ after IPC but found no effect of either duration on performance. Lisbôa et al. (2017) examined time-dependent effects of IPC on $50 \mathrm{~m}$ swim performance at $1 \mathrm{~h}, 2 \mathrm{~h}$, and $8 \mathrm{~h}$ following IPC. They did not find improved performance within $1 \mathrm{~h}$ of IPC despite showing clear benefits in the $2 \mathrm{~h}$ and $8 \mathrm{~h}$ trials which may point to a delayed onset of ergogenic effects. This, however, does not explain the bulk of studies that have found performance enhancement within the first hour 
after IPC (Jean-St-Michel et al., 2011; Marocolo et al., 2015a, 2016a,b; Cruz et al., 2016; Paradis-Deschênes et al., 2016, 2017, 2018).

Therefore, although most studies have conducted their exercise testing within the first $30 \mathrm{~min}$ of IPC, we can find no evidence of the determination of an optimal time between IPC and exercise. The establishment of guidelines for IPC protocols will be challenging at best and lack empirical support until the potential time-dependent effects of IPC and exercise performance are clarified.

\section{Is IPC a Placebo Effect?}

Due to the obvious differences in the subjective sensation of limb arterial occlusion vs. a low-pressure sham condition, it is inherently challenging to incorporate a proper placebo treatment into IPC exercise research. This presents challenges with adequately blinding participants to the treatments being studied and more than likely introduce biases into an investigation. Given these challenges, it is perhaps unsurprising that many previous investigations have forgone the incorporation of placebo treatments into their studies (Marocolo et al., 2015b, 2019). In our review of the literature, we have found that only $33 \%$ of IPC exercise studies have incorporated a placebo intervention in their study design (Table 1). For further clarity, we have defined a placebo as an intervention in which participants were led to believe that the sham treatment would have similar outcomes to the IPC treatment. Studies that used low-pressure sham conditions without deception or placebonocebo expectations have been presented as control conditions in our table.

The disconcerting low number of placebo-controlled IPC studies was highlighted previously in a letter to the editor in response to a systematic review by Incognito et al. (2016); the letter reported that $50 \%$ of the studies in the review showing performance benefits did not include a placebo in their study designs (da Mota and Marocolo, 2016). Only $24 \%$ of the investigations that reported performance improvements following IPC in the Incognito et al. review controlled for potential placebo effects.

There is additional earlier evidence suggesting that performance enhancement following IPC may be, at least partly, a placebo effect (Marocolo et al., 2015a, 2016a,b; Sabino-Carvalho et al., 2017). Marocolo et al. (2015a) found no difference between IPC and a low-pressure placebo after discovering significant improvements in $100 \mathrm{~m}$ swimming following IPC compared to a control. Separate reports from the same group found that both IPC and placebo conditions increased the maximal number of repetitions performed during elbow flexion and knee extension exercise compared to baseline testing (Marocolo et al., 2016a,b). Whether these studies indicate a placebo effect or potentially an experimental learning or order effect is difficult to ascertain from the published results. Similarly, Sabino-Carvalho et al. (2017) reported improved time-to-exhaustion after IPC with no differences between IPC and a therapeutic ultrasound sham condition, and no difference between conditions in the measured physiological variables.

There are reports that run counter to the assumption of a placebo effect to IPC. For example, Ferreira et al. (2016) conducted a placebo-nocebo controlled investigation on repeated $50 \mathrm{~m}$ swimming performance. Despite $73 \%$ of participants expecting their performance to improve following the sham condition, only IPC improved swimming performance relative to the control. Similarly, Cheung et al. (2020) reported improved cycling time-to-exhaustion following IPC despite participants reporting negative performance expectations after IPC and positive performance expectations after their sham.

Thus, it remains unclear whether the purported ergogenic effects of IPC are a placebo effect or a physiologically evoked and mediated response to the IPC intervention. The current lack of placebo incorporation in IPC exercise studies is a trend that should be rectified in future investigations. This will require effective techniques aimed to blind participants to the treatment of interest when conducting IPC research. This may be achieved through the incorporation of placebo- nocebo controls or deception when feasible.

\section{CONCLUSION}

This review is intended to raise awareness of the wide range and inconsistencies in methodologies that confound interpretation of the literature about the efficacy of IPC as an ergogenic aid. We highlight the wide-ranging variations in chosen IPC protocols, tourniquet pressures, location of the IPC stimulus, and the time between treatment and exercise as potential sources for the discordant response rates. Furthermore, the importance of incorporating quality placebo treatments into future investigations should not be overlooked. More consistent methodologies are critical to being able to eventually develop evidence-based guidelines for IPC applications designed to enhance athletic performance.

\section{AUTHOR CONTRIBUTIONS}

LO'B and IJ contributed to the writing, reading of this manuscript, contributed to critical revisions of the manuscript, reviewed and approved the final version of this manuscript, and agree to be accountable for the accuracy of the information presented. Collection and interpretation of the literature review was undertaken by LO'B. Drafting and formatting of the article was undertaken by LO'B and IJ. All authors contributed to the article and approved the submitted version.

\section{FUNDING}

LO'B was supported by the University of Toronto, Faculty of Kinesiology and Physical Education. 


\section{REFERENCES}

Andreas, M., Schmid, A. I., Keilani, M., Doberer, D., Bartko, J., Crevenna, R., et al. (2011). Effect of ischemic preconditioning in skeletal muscle measured by functional magnetic resonance imaging and spectroscopy: a randomized crossover trial. J. Cardiovasc. Magn. Reson. 13, 1-10. doi: 10.1186/1532-429X-13-32

Arriel, R. A., de Souza, H. L. R., da Mota, G. R., and Marocolo, M. (2018). Declines in exercise performance are prevented 24 hours after postexercise ischemic conditioning in amateur cyclists. PLOS ONE 13:e0207053. doi: 10.1371/journal.pone. 0207053

Arriel, R. A., Meireles, A., Hohl, R., and Marocolo, M. (2020). Ischemic preconditioning improves performance and accelerates the heart rate recovery. J. Sports Med. Phys. Fitness 60, 1209-1215. doi: 10.23736/S0022-4707.20.10822-3

Baikoglu, S. B., and Kaldirimci, M. (2019). Effect of ischemic pre-conditioning on lactate and anaerobic performance. Acta Medica Mediterr. 35, 159-164. doi: 10.19193/0393-6384_2019_1_25

Bailey, T. G., Jones, H., Gregson, W., Atkinson, G., Cable, N. T., and Thijssen, D. H. J. (2012). Effect of ischemic preconditioning on lactate accumulation and running performance. Med. Sci. Sports Exerc. 44, 2084-2089. doi: 10.1249/MSS.0b013e318262cb17

Banks, L., Wells, G. D., Clarizia, N. A., Jean-St-Michel, E., McKillop, A. L., Redington, A. N., et al. (2016). Short-term remote ischemic preconditioning is not associated with improved blood pressure and exercise capacity in young adults. Appl. Physiol. Nutr. Metab. 41, 903-906. doi: 10.1139/apnm-2016-0024

Barbosa, T. C., Machado, A. C., Braz, I. D., Fernandes, I. A., Vianna, L. C., Nobrega, A. C. L., et al. (2015). Remote ischemic preconditioning delays fatigue development during handgrip exercise. Scand. J. Med. Sci. Sport. 25, 356-364. doi: $10.1111 /$ sms.12229

Beaven, C. M., Cook, C. J., Kilduff, L., Drawer, S., and Gill, N. (2012). Intermittent lower-limb occlusion enhances recovery after strenuous exercise. Appl. Physiol. Nutr. Metab. 37, 1132-1139. doi: 10.1139/h2012-101

Behrens, M., Zschorlich, V., Mittlmeier, T., Bruhn, S., and Husmann, F. (2020). Ischemic preconditioning did not affect central and peripheral factors of performance fatigability after submaximal isometric exercise. Front. Physiol. 11:371. doi: 10.3389/fphys.2020.00371

Brown, H., Binnie, M. J., Dawson, B., Bullock, N., Scott, B. R., and Peeling, P. (2018). Factors affecting occlusion pressure and ischemic preconditioning. Eur. J. Sport Sci. 18, 387-396. doi: 10.1080/17461391.2017.1421712

Caru, M., Lalonde, F., Daigle, C., Comtois, A. S., and Curnier, D. (2019a). The effect of remote ischemic preconditioning at moderate- and high-intensity steadystate cycling exercise amongst amateur athletes. Med. dello Sport 72, 317-330. doi: 10.23736/S0025-7826.19.03508-7

Caru, M., Lalonde, F., Gravel, H., Daigle, C., Tournoux, F., Jacquemet, V., et al. (2016). Remote ischaemic preconditioning shortens QT intervals during exercise in healthy subjects. Eur. J. Sport Sci. 16, 1005-1013. doi: $10.1080 / 17461391.2016 .1156161$

Caru, M., Levesque, A., Lalonde, F., and Curnier, D. (2019b). An overview of ischemic preconditioning in exercise performance: a systematic review. J. Sport Heal. Sci. 8, 355-369. doi: 10.1016/j.jshs.2019.01.008

Carvalho, L., and Barroso, R. (2019a). Effects of ischemic preconditioning on the isometric test variables. Sci. Sport. 34, e225-e228. doi: 10.1016/j.scispo.2018.08.011

Carvalho, L., and Barroso, R. (2019b). Ischemic preconditioning improves strength endurance performance. J. Strength Cond. Res. 33, 3332-3337. doi: $10.1519 /$ JSC. 0000000000002846

Cheung, C. P., Slysz, J. T., and Burr, J. F. (2020). Ischemic preconditioning: improved cycling performance despite nocebo expectation. Int. J. Sports Physiol. Perform. 15, 354-360. doi: 10.1123/ijspp.2019-0290

Clevidence, M. W., Mowery, R. E., and Kushnick, M. R. (2012). The effects of ischemic preconditioning on aerobic and anaerobic variables associated with submaximal cycling performance. Eur. J. Appl. Physiol. 112, 3649-3654. doi: $10.1007 / \mathrm{s} 00421-012-2345-5$

Cocking, S., Cable, N. T., Wilson, M. G., Green, D. J., Thijssen, D. H. J., and Jones, H. (2018a). Conduit artery diameter during exercise is enhanced after local, but not remote ischemic preconditioning. Front. Physiol. 9:435. doi: $10.3389 /$ fphys.2018.00435

Cocking, S., Landman, T., Benson, M., Lord, R., Jones, H., Gaze, D., et al. (2017). The impact of remote ischemic preconditioning on cardiac biomarker and functional response to endurance exercise. Scand. J. Med. Sci. Sport. 27, 1061-1069. doi: 10.1111/sms.12724

Cocking, S., Wilson, M. G., Nichols, D., Cable, N. T., Green, D. J., Thijssen, D. H. J., et al. (2018b). Is there an optimal ischemic-preconditioning dose to improve cycling performance? Int. J. Sports Physiol. Perform. 13, 274-282. doi: 10.1123/ijspp.2017-0114

Cohen, M. V., Baines, C. P., and Downey, J. M. (2000). Ischemic preconditioning: from adenosine receptor to K ATP channel. Annu. Rev. Physiol. 62, 79-109. doi: 10.1146/annurev.physiol.62.1.79

Crenshaw, A. G., Hargens, A. R., Gershuni, D. H., and Rydevik, B. (1988). Wide tourniquet cuffs more effective at lower inflation pressures. Acta Orthop. 59, 447-451. doi: 10.3109/17453678809149401

Crisafulli, A., Tangianu, F., Tocco, F., Concu, A., Mameli, O., Mulliri, G., et al. (2011). Ischemic preconditioning of the muscle improves maximal exercise performance but not maximal oxygen uptake in humans. J. Appl. Physiol. 111, 530-536. doi: 10.1152/japplphysiol.00266.2011

Cruz, R. S., Alves de Aguiar, R., Turnes, T., Leonardo Pereira, K., Caputo, F., Rso, C., et al. (2015). Effects of ischemic preconditioning on maximal constant-load cycling performance. J Appl Physiol. 119, 961-967. doi: 10.1152/japplphysiol.00498.2015

Cruz, R. S., De Aguiar, R. A., Turnes, T., Salvador, A. F., and Caputo, F. (2016). Effects of ischemic preconditioning on short-duration cycling performance. Appl. Physiol. Nutr. Metab. 41, 825-831. doi: 10.1139/apnm-2015-0646

da Mota, G. R., and Marocolo, M. (2016). The effects of ischemic preconditioning on human exercise performance: a counterpoint. Sport. Med. 46, 1575-1576. doi: 10.1007/s40279-016-0595-9

da Mota, G. R., Willis, S. J., Sobral, N. D. S., Borrani, F., Billaut, F., and Millet, G. P. (2019). Ischemic preconditioning maintains performance on two 5-km time trials in hypoxia. Med. Sci. Sports Exerc. 51, 2309-2317. doi: 10.1249/MSS.0000000000002049

De Groot, P. C. E., Thijssen, D. H. J., Sanchez, M., Ellenkamp, R., and Hopman, M. T. E. (2010). Ischemic preconditioning improves maximal performance in humans. Eur. J. Appl. Physiol. 108, 141-146. doi: 10.1007/s00421-009-1195-2

Dickson, E., Porcaro, W., Fenton, R., Heard, S., Reindhardt, C., Renzi, F., et al. (2000). Preconditioning at a distance in the isolated rabbit heart. Acad. Emerg. Med. 7, 311-317. doi: 10.1111/j.1553-2712.2000.tb02228.x

El Messaoudi, S., Vissers, A., Thijssen, D., Riksen, N. P., and Rongen, G. A. (2013). The effect of remote ischemic preconditioning on exercise-induced plasma troponin i appearance in healthy volunteers. Int. J. Cardiol. 168, 1612-1613. doi: 10.1016/j.ijcard.2013.01.029

Enko, K., Nakamura, K., Yunoki, K., Miyoshi, T., Akagi, S., Yoshida, M., et al. (2011). Intermittent arm ischemia induces vasodilatation of the contralateral upper limb. J. Physiol. Sci. 61, 507-513. doi: 10.1007/s12576-011-0172-9

Ferreira, T. N., Sabino-Carvalho, J. L. C., Lopes, T. R., Ribeiro, I. C., Succi, J. E., Da Silva, A. C., et al. (2016). Ischemic preconditioning and repeated sprint swimming: a placebo and nocebo study. Med. Sci. Sports Exerc. 48, 1967-1975. doi: 10.1249/MSS.0000000000000977

Foster, G. P., Westerdahl, D. E., Foster, L. A., Hsu, J. V., and Anholm, J. D. (2011). Ischemic preconditioning of the lower extremity attenuates the normal hypoxic increase in pulmonary artery systolic pressure. Respir. Physiol. Neurobiol. 179, 248-253. doi: 10.1016/j.resp.2011.09.001

Franz, A., Behringer, M., Harmsen, J. F., Mayer, C., Krauspe, R., Zilkens, C., et al. (2018). Ischemic preconditioning blunts nuscle damage responses induced by eccentric exercise. Med. Sci. Sports Exerc. 50, 109-115. doi: 10.1249/MSS.0000000000001406

Garcia, C., da Mota, G., Leicht, A., and Marocolo, M. (2017). Ischemic preconditioning and acute recovery of performance in rugby union players. Sport. Med. Int. Open 01, E107-E112. doi: 10.1055/s-0043-111082

Gibson, N., Mahony, B., Tracey, C., Fawkner, S., and Murray, A. (2015). Effect of ischemic preconditioning on repeated sprint ability in team sport athletes. J. Sports Sci. 33, 1182-1188. doi: 10.1080/02640414.2014.988741

Gibson, N., White, J., Neish, M., and Murray, A. (2013). Effect of ischemic preconditioning on land-based sprinting in team-sport athletes. Int. J. Sports Physiol. Perform. 8, 671-676. doi: 10.1123/ijspp.8.6.671

Graham, B., Breault, M. J., McEwen, J. A., and McGraw, R. W. (1993). Occlusion of arterial flow in the extremities at subsystolic pressures through the use of wide tourniquet cuffs. Clin. Orthop. Relat. Res. 286, 257-261. doi: 10.1097/00003086-199301000-00038

Griffin, P. J., Ferguson, R. A., Gissane, C., Bailey, S. J., and Patterson, S. D. (2018). Ischemic preconditioning enhances critical power during a 3 minute 
all-out cycling test. J. Sports Sci. 36, 1038-1043. doi: 10.1080/02640414.2017.13 49923

Griffin, P. J., Hughes, L., Gissane, C., and Patterson, S. D. (2019). Effects of local versus remote ischemic preconditioning on repeated sprint running performance. J. Sports Med. Phys. Fitness, 187-194. doi: 10.23736/S0022-4707.18.08400-1

Halley, S. L., Marshall, P., and Siegler, J. C. (2018). The effect of ischaemic preconditioning on central and peripheral fatiguing mechanisms in humans following sustained maximal isometric exercise. Exp. Physiol. 103, 976-984. doi: 10.1113/EP086981

Halley, S. L., Marshall, P., and Siegler, J. C. (2019). Effect of ischemic preconditioning and changing inspired $\mathrm{O} 2$ fractions on neuromuscular function during intense exercise. J. Appl. Physiol. 127, 1688-1697. doi: 10.1152/japplphysiol.00539.2019

Hittinger, E. A., Maher, J. L., Nash, M. S., Perry, A. C., Signorile, J. F., Kressler, J., et al. (2014). Ischemic preconditioning does not improve peak exercise capacity at sea level or simulated high altitude in trained male cyclists. Appl. Physiol. Nutr. Metab. 40, 65-71. doi: 10.1139/apnm-2014-0080

Huang, B. H., Wang, T. Y., Lu, K. H., Chang, C. Y., and Chan, K. H. (2020). Effects of ischemic preconditioning on local hemodynamics and isokinetic muscular function. Isokinet. Exerc. Sci. 28, 73-81. doi: 10.3233/IES-194184

Incognito, A. V., Burr, J. F., and Millar, P. J. (2016). The effects of ischemic preconditioning on human exercise performance. Sport. Med. 46, 531-544. doi: 10.1007/s40279-015-0433-5

James, C. A., Willmott, A. G. B., Richardson, A. J., Watt, P. W., and Maxwell, N. S. (2016). Ischaemic preconditioning does not alter the determinants of endurance running performance in the heat. Eur. J. Appl. Physiol. 116, 1735-1745. doi: 10.1007/s00421-016-3430-y

Jean-St-Michel, E., Manlhiot, C., Li, J., Tropak, M., Michelsen, M. M., Schmidt, M. R., et al. (2011). Remote preconditioning improves maximal performance in highly trained athletes. Med. Sci. Sports Exerc. 43, 1280-1286. doi: 10.1249/MSS.0b013e318206845d

Jeffries, O., Evans, D. T., Waldron, M., Coussens, A., and Patterson, S. D. (2019). Seven-day ischaemic preconditioning improves muscle efficiency during cycling. J. Sports Sci. 37, 2798-2805. doi: 10.1080/02640414.2019.1664537

Johnson, P. C., Burton, K. S., Henrich, H., and Henrich, U. (1976). Effect of occlusion duration on reactive hyperemia in sartorius muscle capillaries. Am. J. Physiol. 230, 715-719. doi: 10.1152/ajplegacy.1976.230.3.715

Kaur, G., Binger, M., Evans, C., Trachte, T., and Van Guilder, G. P. (2017). No influence of ischemic preconditioning on running economy. Eur. J. Appl. Physiol. 117, 225-235. doi: 10.1007/s00421-016-3522-8

Kido, K., Suga, T., Tanaka, D., Honjo, T., Homma, T., Fujita, S., et al. (2015). Ischemic preconditioning accelerates muscle deoxygenation dynamics and enhances exercise endurance during the work-to-work test. Physiol. Rep. 3, 1-10. doi: 10.14814/phy2.12395

Kilding, A. E., Sequeira, . G. M., and Wood, · M. R. (2018). Effects of ischemic preconditioning on economy, VO 2 kinetics and cycling performance in endurance athletes. Eur. J. Appl. Physiol. 118, 2541-2549. doi: 10.1007/s00421-018-3979-8

Kjeld, T., Rasmussen, M. R., Jattu, T., Nielsen, H. B., and Secher, N. H. (2014). Ischemic preconditioning of one forearm enhances static and dynamic apnea. Med. Sci. Sports Exerc. 46, 151-155. doi: 10.1249/MSS.0b013e3182a4090a

Konstantinov, I. E., Li, J., Cheung, M. M., Shimizu, M., Stokoe, J., Kharbanda, R. K., et al. (2005). Remote ischemic preconditioning of the recipient reduces myocardial ischemia-reperfusion injury of the denervated donor heart via a Katp channel-dependent mechanism. Transplantation 79, 1691-1695. doi: 10.1097/01.TP.0000159137.76400.5D

Kraus, A. S., Pasha, E. P., Machin, D. R., Alkatan, M., Kloner, R. A., and Tanaka, H. (2015). Bilateral upper limb remote ischemic preconditioning improves anaerobic power. Open Sport. Med. J. 9, 1-6. doi: 10.2174/1874387001509010001

Kristiansen, S. B., Henning, O., Kharbanda, R. K., Nielsen-Kudsk, J. E., Schmidt, M. R., Redington, A. N., et al. (2005). Remote preconditioning reduces ischemic injury in the explanted heart by a KATP channel-dependent mechanism. Am. J. Physiol. Hear. Circ. Physiol. 288, 1252-1256. doi: 10.1152/ajpheart.00207.2004

Lalonde, F., and Curnier, D. (2015). Can anaerobic performance be improved by remote ischemic preconditioning? J. Strength Cond. Res. 29, 80-85. doi: 10.1519/JSC.0000000000000609
Libonati, J. R., Cox, M., Incanno, N., Melville, S. K., Musante, F. C., Glassberg, H. L., et al. (1998). Brief periods of occlusion and reperfusion increase skeletal muscle force output in humans - PubMed. Cardiologia 43, 1355-1360.

Lindsay, A., Petersen, C., Blackwell, G., Ferguson, H., Parker, G., Steyn, N., et al. (2017). The effect of 1 week of repeated ischaemic leg preconditioning on simulated Keirin cycling performance: a randomised trial. BMJ Open Sport Exerc. Med. 3, 1-8. doi: 10.1136/bmjsem-2017-000229

Lisbôa, F. D., Turnes, T., Cruz, R. S. O., Raimundo, J. A. G., Pereira, G. S., and Caputo, F. (2017). The time dependence of the effect of ischemic preconditioning on successive sprint swimming performance. J. Sci. Med. Sport 20, 507-511. doi: 10.1016/j.jsams.2016.09.008

Liu, Z. J., Chen, C., Li, X. R., Ran, Y. Y., Xu, T., Zhang, Y., et al. (2016). Remote ischemic preconditioning-mediated neuroprotection against stroke is associated with significant alterations in peripheral immune responses. CNS Neurosci. Ther. 22, 43-52. doi: 10.1111/cns.12448

Loenneke, J. P., Allen, K. M., Mouser, J. G., Thiebaud, R. S., Kim, D., Abe, T., et al. (2015). Blood flow restriction in the upper and lower limbs is predicted by limb circumference and systolic blood pressure. Eur. J. Appl. Physiol. 115, 397-405. doi: 10.1007/s00421-014-3030-7

Loenneke, J. P., Fahs, C. A., Rossow, L. M., Sherk, V. D., Thiebaud, R. S., Abe, T., et al. (2012). Effects of cuff width on arterial occlusion: implications for blood flow restricted exercise. Eur. J. Appl. Physiol. 112, 2903-2912. doi: 10.1007/s00421-011-2266-8

Loenneke, J. P., Thiebaud, R. S., Fahs, C. A., Rossow, L. M., Abe, T., and Bemben, M. G. (2013). Effect of cuff type on arterial occlusion. Clin. Physiol. Funct. Imaging 33, 325-327. doi: 10.1111/cpf.12035

Lopes, T. R., Sabino-Carvalho, J. L., Ferreira, T. H. N., Succi, J. E., Silva, A. C., and Silva, B. M. (2018). Effect of ischemic preconditioning on the recovery of cardiac autonomic control from repeated sprint exercise. Front. Physiol. 9:1465. doi: 10.3389/fphys.2018.01465

Marocolo, I. C., da Mota, G. R., Londe, A. M., Patterson, S. D., Neto, O. B., and Marocolo, M. (2017). Acute ischemic preconditioning does not influence high-intensity intermittent exercise performance. PeerJ 2017, 1-13. doi: $10.7717 /$ peerj. 4118

Marocolo, M., da Mota, G., Pelegrini, V., and Appell Coriolano, H.-J. (2015a). Are the beneficial effects of ischemic preconditioning on performance partly a placebo effect? Int. J. Sports Med. 36, 822-825. doi: 10.1055/s-0035-1549857

Marocolo, M., Da Mota, G. R., Simim, M. A. M., and Appell Coriolano, H. J. (2015b). Myths and facts about the effects of ischemic preconditioning on performance. Int. J. Sports Med. 37, 87-96. doi: 10.1055/s-0035-1564253

Marocolo, M., Marocolo, I. C., Da Mota, G. R., Simão, R., Maior, A. S., and Coriolano, H. J. A. (2016a). Beneficial effects of ischemic preconditioning in resistance exercise fade over time. Int. J. Sports Med. 37, 819-824. doi: 10.1055/s-0042-109066

Marocolo, M., Simim, M. A. M., Bernardino, A., Monteiro, I. R., Patterson, S. D., and da Mota, G. R. (2019). Ischemic preconditioning and exercise performance: shedding light through smallest worthwhile change. Eur. J. Appl. Physiol. 119, 2123-2149. doi: 10.1007/s00421-019-04214-6

Marocolo, M., Willardson, J. M., Marocolo, I. C., Ribeiro Da Mota, G., Simão, R., and Maior, A. S. (2016b). Ischemic preconditioning and placebo intervention improves resistance exercise performance. J. Strength Cond. Res. 30, 1462-1469. doi: 10.1519/JSC.0000000000001232

Marongiu, E., and Crisafulli, A. (2014). Cardioprotection acquired through exercise: the role of ischemic preconditioning. Curr. Cardiol. Rev. 10, 336-348. doi: 10.2174/1573403X10666140404110229

McIlvenna, L. C., Muggeridge, D. J., Forrest (Nee Whyte), L. J., Monaghan, C., Liddle, L., Burleigh, M. C., et al. (2019). Lower limb ischemic preconditioning combined with dietary nitrate supplementation does not influence timetrial performance in well-trained cyclists. J. Sci. Med. Sport 22, 852-857. doi: 10.1016/j.jsams.2019.01.011

Mieszkowski, J., Stankiewicz, B., Kochanowicz, A., Niespodziński, B., Borkowska, A., and Antosiewicz, J. (2020). Effect of ischemic preconditioning on marathoninduced changes in serum exerkine levels and inflammation. Front. Physiol. 11:571220. doi: 10.3389/fphys.2020.571220

Mota, G. R., Rightmire, Z. B., Martin, J. S., McDonald, J. R., Kavazis, A. N., Pascoe, D. D., et al. (2020). Ischemic preconditioning has no effect on maximal arm cycling exercise in women. Eur. J. Appl. Physiol. 120, 369-380. doi: 10.1007/s00421-019-04281-9 
Murphy, C. G., Winter, D. C., and Bouchier-Hayes, D. J. (2005). Tourniquet injuries: pathogenesis and modalities for attenuation - PubMed. Acta Orthop. Belg. 71, 635-645.

Murry, C. E., Jennings, R. B., and Reimer, K. A. (1986). Preconditioning with ischemia: a delay of lethal cell injury in ischemic myocardium. Circulation 74, 1124-1136. doi: 10.1161/01.CIR.74.5.1124

Ochoa, J., Fowler, T. J., and Gilliatt, R. W. (1972). Anatomical changes in peripheral nerves compressed by a pneumatic tourniquet. J Anat 133, 433-455.

Pagliaro, P., Gattullo, D., Rastaldo, R., and Losano, G. (2001). Ischemic preconditioning - from the first to the second window of protection. Life Sci. 69, 1-15. doi: 10.1016/S0024-3205(01)01113-4

Paixão, R. C., Da Mota, G. R., and Marocolo, M. (2014). Acute effect of ischemic preconditioning is detrimental to anaerobic performance in cyclists. Int. J. Sports Med. 35, 912-915. doi: 10.1055/s-0034-1372628

Paradis-Deschênes, P., Joanisse, D. R., and Billaut, F. (2016). Ischemic preconditioning increases muscle perfusion, oxygen uptake, and force in strength-trained athletes. Appl. Physiol. Nutr. Metab. 41, 938-944. doi: 10.1139/apnm-2015-0561

Paradis-Deschênes, P., Joanisse, D. R., and Billaut, F. (2017). Sex-specific impact of ischemic preconditioning on tissue oxygenation and maximal concentric force. Front. Physiol. 7:674. doi: 10.3389/fphys.2016.00674

Paradis-Deschênes, P., Joanisse, D. R., and Billaut, F. (2018). Ischemic preconditioning improves time trial performance at moderate altitude. Med. Sci. Sports Exerc. 50, 533-541. doi: 10.1249/MSS.0000000000001473

Paradis-Deschênes, P., Joanisse, D. R., Mauriège, P., and Billaut, F. (2020a). Ischemic preconditioning enhances aerobic adaptations to sprint-interval training in athletes without altering systemic hypoxic signaling and immune function. Front. Sport. Act. Living 2:41. doi: 10.3389/fspor.2020.00041

Paradis-Deschênes, P., Lapointe, J., Joanisse, D. R., and Billaut, F. (2020b). Similar recovery of maximal cycling performance after ischemic preconditioning, neuromuscular electrical stimulation or active recovery in endurance athletes. J. Sport. Sci. Med. 19, 761-771.

Patterson, S. D., Bezodis, N. E., Glaister, M., and Pattison, J. R. (2015). The effect of ischemic preconditioning on repeated sprint cycling performance. Med. Sci. Sports Exerc. 47, 1652-1658. doi: 10.1249/MSS.0000000000000576

Paull, E. J., and Van Guilder, G. P. (2019). Remote ischemic preconditioning increases accumulated oxygen deficit in middle-distance runners. J. Appl. Physiol. 126, 1193-1203. doi: 10.1152/japplphysiol.00585.2018

Pereira, H. M., de Lima, F. F., Silva, B. M., and Kohn, A. F. (2020). Sex differences in fatigability after ischemic preconditioning of non-exercising limbs. Biol. Sex Differ. 11, 1-13. doi: 10.1186/s13293-020-00338-z

Pérez-Pinzón, M. A. (2004). Neuroprotective effects of ischemic preconditioning in brain mitochondria following cerebral ischemia. J. Bioenerg. Biomembr. 36, 323-327. doi: 10.1023/B:JOBB.0000041762.47544.ff

Richard, P., and Billaut, F. (2018). Time-trial performance in elite speed skaters after remote ischemic preconditioning. Int. J. Sports Physiol. Perform. 13, 1308-1316. doi: 10.1123/ijspp.2018-0111

Sabino-Carvalho, J. L., Lopes, T. R., Obeid-Freitas, T., Ferreira, T. N., Succi, J. E., Silva, A. C., et al. (2017). Effect of ischemic preconditioning on endurance performance does not surpass placebo. Med. Sci. Sports Exerc. 49, 124-132. doi: 10.1249/MSS.0000000000001088

Salvador, A. F., De Aguiar, R. A., Lisbôa, F. D., Pereira, K. L., De Cruz, R. S. O., and Caputo, F. (2016). Ischemic preconditioning and exercise performance: a systematic review and meta-analysis. Int. J. Sports Physiol. Perform. 11, 4-14. doi: 10.1123/ijspp.2015-0204

Seeger, J. P. H., Timmers, S., Ploegmakers, D. J. M., Cable, N. T., Hopman, M. T. E., and Thijssen, D. H. J. (2017). Is delayed ischemic preconditioning as effective on running performance during a $5 \mathrm{~km}$ time trial as acute IPC? J. Sci. Med. Sport 20, 208-212. doi: 10.1016/j.jsams.2016.03.010

Shimizu, M., Konstantinov, I. E., Kharbanda, R. K., Cheung, M. H., and Redington, A. N. (2007). Effects of intermittent lower limb ischaemia on coronary blood flow and coronary resistance in pigs. Acta Physiol. 190, 103-109. doi: 10.1111/j.1748-1716.2007.01667.x

Sieljacks, P., Knudsen, L., Wernbom, M., and Vissing, K. (2018). Body position influences arterial occlusion pressure: implications for the standardization of pressure during blood flow restricted exercise. Eur. J. Appl. Physiol. 118, 303-312. doi: 10.1007/s00421-017-3770-2

Singh, L., Randhawa, P. K., Singh, N., and Jaggi, A. S. (2017). Redox signaling in remote ischemic preconditioning-induced cardioprotection: evidences and mechanisms. Eur. J. Pharmacol. 809, 151-155. doi: 10.1016/j.ejphar.2017.05.033

Slysz, J. T., and Burr, J. F. (2018). Enhanced metabolic stress augments ischemic preconditioning for exercise performance. Front. Physiol. 9:1621. doi: 10.3389/fphys.2018.01621

Slysz, J. T., and Burr, J. F. (2019). Impact of 8 weeks of repeated ischemic preconditioning on running performance. Eur. J. Appl. Physiol. 119, 1431-1437. doi: 10.1007/s00421-019-04133-6

Slysz, J. T., Petrick, H. L., Marrow, J. P., and Burr, J. F. (2019). An examination of individual responses to ischemic preconditioning and the effect of repeated ischemic preconditioning on cycling performance. Eur. J. Sport Sci. 20, 633-640. doi: 10.1080/17461391.2019.1651401

Surkar, S. M., Bland, M. D., Mattlage, A. E., Chen, L., Gidday, J. M., Lee, J. M., et al. (2020). Effects of remote limb ischemic conditioning on muscle strength in healthy young adults: a randomized controlled trial. PLOS ONE 15:e0227263. doi: 10.1371/journal.pone.0227263

Tanaka, D., Suga, T., Tanaka, T., Kido, K., Honjo, T., Fujita, S., et al. (2016). Ischemic preconditioning enhances muscle endurance during sustained isometric exercise. Int. J. Sports Med. 37, 614-618. doi: 10.1055/s-0035-15 65141

Telles, L.uiz, G. D., Cristiano Carelli, L., Dutra Bráz, I., Junqueira, C., Rios Monteiro, E., Machado Reis, V., et al. (2020). Effects of ischemic preconditioning as a warm-up on leg press and bench press performance. $J$. Hum. Kinet. 75, 267-277. doi: 10.2478/hukin-2020-0055

Thompson, K. M. A., Whinton, A. K., Ferth, S., Spriet, L. L., and Burr, J. F. (2018). Ischemic preconditioning: no influence on maximal sprint acceleration performance. Int. J. Sports Physiol. Perform. 13, 986-990. doi: 10.1123/ijspp.2017-0540

Tocco, F., Marongiu, E., Ghiani, G., Sanna, I., Palazzolo, G., Olla, S., et al. (2015). Muscle ischemic preconditioning does not improve performance during selfpaced exercise. Int. J. Sports Med. 36, 9-15. doi: 10.1055/s-0034-1384546

Tomschi, F., Niemann, D., Bloch, W., Predel, H. G., and Grau, M. (2018). Ischemic preconditioning enhances performance and erythrocyte deformability of responders. Int. J. Sports Med. 39, 596-603. doi: 10.1055/a-0631-2887

Turnes, T., Alves de Aguiar, R., Santos de Oliveira Cruz, R., Félix Salvador, A., Domingos Lisbôa, F., Leonardo Pereira, K., et al. (2018). Impact of ischaemia-reperfusion cycles during ischaemic preconditioning on 2000$\mathrm{m}$ rowing ergometer performance. Eur. J. Appl. Physiol. 118, 1599-1607. doi: 10.1007/s00421-018-3891-2

Valenzuela, P. L., Martín-Candilejo, R., Sánchez-Martínez, G., Bouzas Marins, J. C., de la Villa, P., and Sillero-Quintana, M. (2019). Ischemic preconditioning and muscle force capabilities. J. Strength Cond. Res. 1-7. doi: 10.1519/JSC.0000000000003104

Wang, M., Qi, D. S., Zhou, C., Han, D., Li, P. P., Zhang, F., et al. (2016). Ischemic preconditioning protects the brain against injury via inhibiting CaMKII-nNOS signaling pathway. Brain Res. 1634, 140-149. doi: 10.1016/j.brainres.2016.01.008

Wiggins, C. C., Constantini, K., Paris, H. L., Mickleborough, T. D., and Chapman, R. F. (2019). Ischemic preconditioning, O2 kinetics, and performance in normoxia and hypoxia. Med. Sci. Sports Exerc. 51, 900-911. doi: 10.1249/MSS.0000000000001882

Williams, N., Russell, M., Cook, C. J., and Kilduff, L. P. (2018). The effect of ischemic preconditioning on maximal swimming performance. J. Strength Cond. Res. 221-226. doi: 10.1519/JSC.0000000000002485

Zinner, C., Born, D. P., and Sperlich, B. (2017). Ischemic preconditioning does not alter performance in multidirectional high-intensity intermittent exercise. Front. Physiol. 8:1029. doi: 10.3389/fphys.2017.01029

Conflict of Interest: The authors declare that the research was conducted in the absence of any commercial or financial relationships that could be construed as a potential conflict of interest.

Copyright (C) 2021 O'Brien and Jacobs. This is an open-access article distributed under the terms of the Creative Commons Attribution License (CC BY). The use, distribution or reproduction in other forums is permitted, provided the original author(s) and the copyright owner(s) are credited and that the original publication in this journal is cited, in accordance with accepted academic practice. No use, distribution or reproduction is permitted which does not comply with these terms. 